\title{
COMPARISON OF ANTIBACTERIAL ACTIVITY OF LEAVES EXTRACTS OF TECTONA GRANDIS, MANGIFERA INDICA, AND ANACARDIUM OCCIDENTALE
}

\author{
KRISHNANANDA KAMATH K. , A. RAMAKRISHNA SHABARAYA \\ Department of Pharmaceutics, Srinivas College of Pharmacy, Valachil, Mangalore 574143, Karnataka, India \\ Email: kamathkrishnananda@yahoo.com
}

Received: 20 Sep 2016, Revised and Accepted: 15 Nov 2016

\begin{abstract}
Objective: World Health Organization estimated that $80 \%$ of people worldwide rely upon herbal medicines for some aspect of their primary healthcare. For most of the herbs, the specific ingredient that causes therapeutic effect is not known. Bacterial infections are one of the prominent causes of health problems, physical disabilities and mortalities around the world. Plants have been used in medicine as antimicrobial agents since ancient times could provide a promising solution for drug-resistant species. The present study involves comparison of the antibacterial activity of ethanolic extract leaves of Tectona grandis (teak), Mangifera indica (mango), and, Anacardium Occidentale (cashew).
\end{abstract}

Methods: Authentication, morphological studies and phytochemical screening studies on alcoholic extracts of leaves were carried out. Antibacterial activity was carried out by using different concentrations of extracts on bacterial strains of Staphylococcus aureus, Escherichia coli and Pseudomonas aeruginosa by using agar well diffusion method and results were compared.

Results: Preliminary phytochemical screening of extracts revealed the presence of alkaloids, glycosides, saponins, resins, tannins and flavonoids. Antibacterial activity was observed in the concentration range of $25-100 \mathrm{mg} / \mathrm{ml}$ for all the extracts except $T$. grandis leaves. They are effective at 50 $100 \mathrm{mg} / \mathrm{ml}$ concentration.

Conclusion: Comparison of results reveals that leaves of T. Grandis have less antibacterial activity compared to M. Indica and A. Occidantale extracts.

Keywords: Teak, Mango, Cashew Leaves Extracts, Phytochemical Screening, Antibacterial activity

(C) 2016 The Authors. Published by Innovare Academic Sciences Pvt Ltd. This is an open access article under the CC BY license (http://creativecommons.org/licenses/by/4.0/) DOI: http://dx.doi.org/10.22159/ijcpr.2017v9i1.16602

\section{INTRODUCTION}

Herbal medicine has become an item of global importance both as medicinal and economical. The use of plant and plant products for therapeutic use is known since time immemorial. Herbs are used to treat various infectious diseases worldwide. They are most effective, cheaper and alternative sources of drugs. Plants play a vital role in curing various ailments and herbal remedies are getting increasing patient compliance as they are devoid of typical side effects of allopathic medicines. The effective plant constituents can combat human and plant pathogenic bacteria, fungi and virus without any side effects and environmental hazards. Due to this favourable reason, search for plant products with antimicrobial properties intensified in recent years [1-3]. Although usage of these herbal medicines has increased, their quality, safety and efficiency are serious concerns in industrialised and developing countries.

Bacterial infections are one of the prominent causes of health problems, physical disabilities and mortalities around the world. Plants that have been used in medicine as antimicrobial agents since ancient times could provide a promising solution for drug-resistant species. The natural products are found to be more effective with least side effects as compared to commercial antibiotics this is why they are used as an alternate remedy for the treatment of various infections. The most essential of bioactive constituents of plants are alkaloids, tannins, flavonoids and phenolic compounds. Bioactive constituents have found applications as naturally occurring antimicrobial agents in the field of preservation, pharmaceutics, phytopathology, etc. Increasing failure of chemotherapeutics and the resistance exhibited by pathogenic microbial infectious agents against antibiotics have led to the screening of medicinal plants for their potential antimicrobial activities $[4,5]$.

There are several reports regarding the antimicrobial activity of crude extracts prepared from plants. Some of the active principles of the bioactive compounds are preferred for their therapeutic purposes either as a single entity or in combination, so as to inhibit the life processes of microbes [6-7]. Considering above facts present research work was aimed at comparison of the antibacterial activity of leaves extract containing Tectona grandis Linn. Family Verbenaceae, extracts of Mangifera indica (L.), Family Anacardiaceae, and Anacardium occidentale Linn. Family Anacardiaceae. Plants were investigated for antibacterial activity against $S$. aureus, E. coli and $P$. aeruginosa.

\section{MATERIALS AND METHODS}

\section{Materials}

Gentamycin Sulphate USP gift sample procured from Ranbaxy Laboratories Ltd., Madkaim, Ponda, Goa. Microbiological media, Mueller Hinton Agar (MHA) (Himedia) was procured from the department of microbiology, Srinivas College of pharmacy, Mangalore. All the other chemicals used in the formulations were of analytical grade.

\section{Methods}

\section{Collection, identification and extraction}

Fresh leaves of T. grandis, M. indica and A. Occidentale were collected from the coastal region of Udupi district, Karnataka, India in the month of February 2015. The plant leaves were authenticated by Prof. Gopal Krishna Bhat, Department of Botany, Poornaprajna College, Udupi, Karnataka, India. The leaves were washed 2-3 times with running water, air dried under shade and made into coarse powder by using a grinder, stored in airtight containers in cool place.

\section{Soxhlet extraction of dried leaves}

Collected leaves were air-dried, powdered and subjected to soxhlet extraction. Approximately 50 to $60 \mathrm{~g}$ of the powder was extracted with ethyl alcohol. Evaporation of the solvents from the extracts was done by using rotary vacuum evaporator at $35-50^{\circ} \mathrm{C}$. A sticky mass was obtained after evaporation of extracts, labelled and stored at 2 $8^{\circ} \mathrm{C}$. The percentage yields were calculated [8]. 
Table 1: Parameters used for extraction from dried leaves

\begin{tabular}{llll}
\hline Parameters & T. grandis & M. indica & A. occidenatle \\
\hline Dried powder taken & $55 \mathrm{~g}$ & $58 \mathrm{~g}$ & $55 \mathrm{~g}$ \\
Amt. Ethanol taken & $350 \mathrm{ml}$ & $350 \mathrm{ml}$ & $350 \mathrm{ml}$ \\
Time taken for extraction & $5 \mathrm{~h}$ & $5 \mathrm{~h}$ & $5 \mathrm{~h}$ \\
RPM of rotary evaporator & $40-45 \mathrm{RPM}$ & $35-40 \mathrm{RPM}$ & $35-40 \mathrm{RPM}$ \\
Temp. of water bath & $35-45^{\circ} \mathrm{C}$ & $40-50^{\circ} \mathrm{C}$ & $40-50^{\circ} \mathrm{C}$ \\
Wt. of extract. & $9.54 \mathrm{~g}$ & $11.68 \mathrm{~g}$ & $10.48 \mathrm{~g}$ \\
\%Yield (w/w) & $17.34 \%$ & $20.13 \%$ & $19.05 \%$ \\
Alcoholic extract Color & Dark red color & Greenish Yellow color & Greenish color \\
\hline
\end{tabular}

\section{Preliminary phytochemical screening}

Extracts from the leaves were subjected to qualitative analysis (table 2) to check the presence alkaloids, carbohydrates, glycosides, saponins, phytosterols, fixed oils and fats, resins, phenols, tannins, flavonoids, proteins, amino acids, and triterpenoids [8-10,13].

\section{In vitro antibacterial activity of extracts of plants}

Ethanol extracts of $T$. grandis, $M$. indica and $A$. occidentale were dissolved in a few drops of Dimethylsulfoxide (DMSO) and made up with distilled water to give a stock solution of $100 \mathrm{mg} / \mathrm{ml}$ separately. From this stock solution 25, 50 and $75 \mathrm{mg} / \mathrm{ml}$ concentrations were prepared. The stock solutions were kept at $4-8^{\circ} \mathrm{C}$. Standard bacterial organisms from the ATCC were obtained from the department of microbiology, Srinivas College of pharmacy, Mangalore. S. aureus (ATCC25923), E. coli (ATCC 25922) and P. aeruginosa (ATCC 27853) were used. The organisms were first isolated on nutrient broth for 24 $\mathrm{h}$ and then diluted to 1:1000 with the sterile nutrient dextrose broth. The dilutions formed were used as bacterial stock solutions for the agar-well diffusion assays.

\section{Preparation of media, Direct sensitivity testing}

Mueller Hinton agar media was used. The media was prepared by adding $11.40 \mathrm{~g}$ of agar powder to $300 \mathrm{ml}$ of distilled water and the mixture was boiled. The solution was autoclaved at $121^{\circ} \mathrm{C}$ for $15 \mathrm{~min}$ and cooled to $50^{\circ} \mathrm{C}$ in a water bath. It was then transferred into sterile plates. It was allowed to cool and solidify under sterile conditions and then incubated for $24 \mathrm{~h}$ at $37^{\circ} \mathrm{C}$ to ensure that there is no bacterial contamination. Wells of $6 \mathrm{~mm}$ diameter and $5 \mathrm{~mm}$ depth were made in the solidified agar using a sterile borer.

\begin{abstract}
Agar-well diffusion assay
Cultures of E. coli, S. aureus and P. aeruginosa were inoculated separately onto agar before solidifying. Then it was transferred to each Petri dish. Prepared $1 \mathrm{ml}$ extracts of concentration 25, $50,75,100 \mathrm{mg} / \mathrm{ml}$ of the test and $10 \mu \mathrm{g} / \mathrm{ml}$ of Gentamycin Sulphate USP (positive control) were dispensed into the wells. The plates were incubated at $37^{\circ} \mathrm{C}$ for $24 \mathrm{~h}$. The sensitivity of the test organisms to the all the three above extracts was determined by measuring the diameters of the zone of inhibition surrounding the wells $[11,12]$.
\end{abstract}

\section{RESULTS AND DISCUSSION}

Morphology of leaves was studied and complies with the specifications. Plant leaves are depicted in fig. 1, 2 and 3.

\section{In vitro antibacterial activity of ethanolic extracts of plants}

The extracts were studied for antibacterial activities of using agar well diffusion method; results are depicted in table 3 . The selected test organisms used in this study are associated with various forms of human infections. These organisms are common causes of infections in a patient with burns and other types of wounds. Gentamicin sulphate USP, used as the positive control, showed sensitivity to test organisms with $25-29 \mathrm{~mm}$ of zone diameter showed a maximum inhibitory effect compared to leaves extracts. Ethanol extract of T. Grandis with concentration $25 \mathrm{mg} / \mathrm{ml}$ did not show any effect on the growth of microorganisms, Only 50, 75 and $100 \mathrm{mg} / \mathrm{ml}$ concentrations were effective.

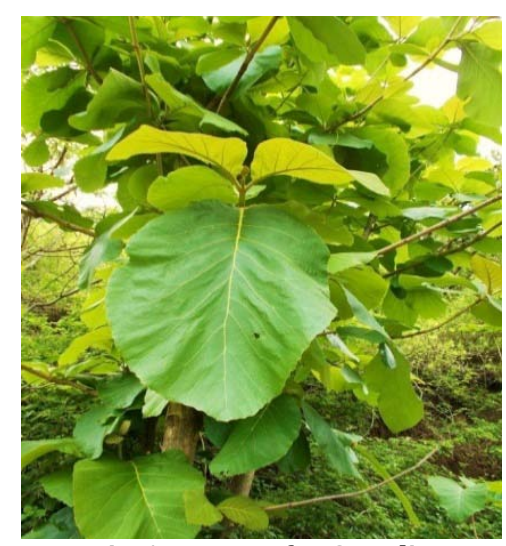

Fig. 1: Leaves of T. Grandis

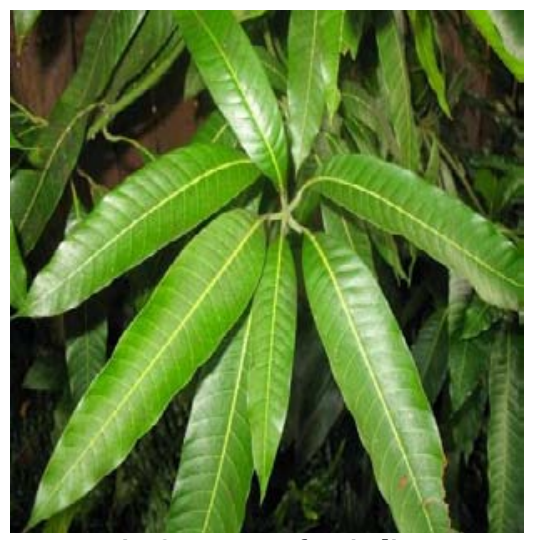

Fig. 2: Leaves of $M$. indica

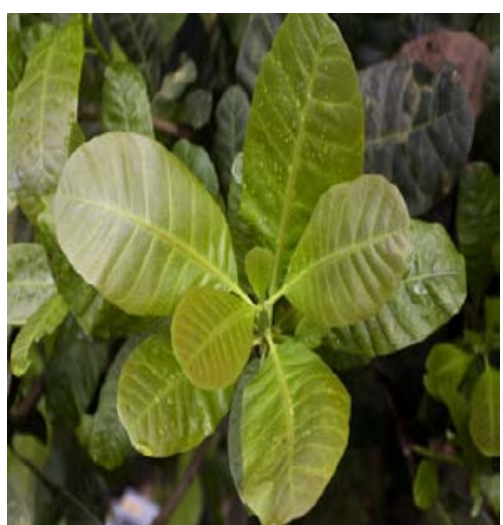

Fig. 3: Leaves of A. Occidantale

Preliminary phytochemical screening of extracts was done and revealed the presence of alkaloids, glycosides, saponins, resins, tannins, phenols and flavonoids as represented in table 2.

In the case of $M$. Indica and $A$. Occidentale, all test concentrations were effective. Extract of $A$. Occidentale gave maximum zones of inhibition for $25,50,75$ and $100 \mathrm{mg} / \mathrm{ml}$ concentration respectively (table 3 ) when compared to other extracts.

The antibacterial activity could be due to different classes of compounds present in extracts. Some of the classes of compounds identified in the crude extract were mainly alkaloids, phenols, flavonoids, and tannins have been reported to possess antibacterial activity [13-16]. Further fractionation of the extracts could yield fractions or compounds with higher antibacterial activity. The antibacterial activity of herbal plants is may be due to adsorption of polyphenols to bacterial membranes with disruption of the membrane and subsequent leakage of cellular contents. In this study, ethanolic $A$. Occidentale leaves contains the phenolic active compound, such as anacardic acid which shows antimicrobial effect [17-21]. 
Table 2: Phytochemical Screening of extracts of T. Grandis, M. indica and A. Occidentale

\begin{tabular}{|c|c|c|c|c|}
\hline Chemical constituents & Tests & T. Grandis & M. indica & A. Occidentale \\
\hline \multirow[t]{4}{*}{ Alkaloids } & 1. Mayer's test & + & + & + \\
\hline & 2. Dragendroffs test & + & + & + \\
\hline & 3. Wagners test & + & + & + \\
\hline & 4. Hagers test & + & + & + \\
\hline \multirow[t]{4}{*}{ Carbohydrates } & 1. Molischs Test & - & + & + \\
\hline & 2. Bendicts test & - & + & + \\
\hline & 3. Fehlings test & - & + & + \\
\hline & 4. Barfoed's Test & - & + & + \\
\hline \multirow[t]{2}{*}{ Glycosides } & 1. Brontagers test & - & + & _ \\
\hline & 2. Legal Test & - & + & - \\
\hline \multirow[t]{2}{*}{ Saponionis } & 1. Foam test & + & - & + \\
\hline & 2. Froth Test & + & _- & + \\
\hline \multirow[t]{2}{*}{ Phytosterols } & 1. Salkowski test & - & - & + \\
\hline & 2. Leibermann Burchard test & - & - & + \\
\hline Fat and Oils & 1. Stain test & - & - & + \\
\hline Resins & 1. Acetone and water test & + & + & + \\
\hline Phenols & 1. Ferric Chloride test & - & + & + \\
\hline \multirow[t]{2}{*}{ Tannins } & 1. Alkaline reagent test & - & + & + \\
\hline & 2. Gelatin test & - & + & + \\
\hline \multirow[t]{4}{*}{ Flavonoids test } & 1. Lead Acetate test & + & + & + \\
\hline & 2. Shinoda test & + & + & + \\
\hline & 3. $\mathrm{Zn}-\mathrm{HCl}$ reduction test & + & + & + \\
\hline & 4. Alkaline reagent test & + & + & + \\
\hline
\end{tabular}

Table 3: Antibacterial activity of leaves extracts of T. Grandis M. Indica A. Occidentale Diameter of zone inhibition (mm)

\begin{tabular}{|c|c|c|c|c|c|c|c|c|c|}
\hline \multirow{2}{*}{$\begin{array}{l}\text { Leaves extract conc. } \\
\text { (mg/ml) }\end{array}$} & \multicolumn{3}{|l|}{ S. aureus } & \multicolumn{3}{|l|}{ E. coli } & \multicolumn{3}{|c|}{ P. aeruginosa } \\
\hline & $\begin{array}{l}T \\
\text { Grandis }\end{array}$ & $\begin{array}{l}\text { M. } \\
\text { indica } \\
\end{array}$ & $\begin{array}{l}\text { A. } \\
\text { occidentale }\end{array}$ & $\begin{array}{l}\text { T } \\
\text { Grandis }\end{array}$ & $\begin{array}{l}\text { M. } \\
\text { indica }\end{array}$ & $\begin{array}{l}\text { A. } \\
\text { occidentale }\end{array}$ & $\begin{array}{l}\text { Trandis } \\
\text { Grand }\end{array}$ & $\begin{array}{l}\text { M. } \\
\text { indica }\end{array}$ & $\begin{array}{l}\text { A. } \\
\text { occidentale }\end{array}$ \\
\hline 25 & Nil & $6-8$ & $6-9$ & Nil & $5-8$ & $6-9$ & Nil & $5-7$ & $7-10$ \\
\hline 50 & $6-8$ & 8-12 & $11-14$ & $6-9$ & $9-11$ & $10-12$ & $7-9$ & $10-12$ & $11-13$ \\
\hline 75 & $7-9$ & $13-15$ & $16-19$ & $9-10$ & $11-14$ & $16-18$ & $8-10$ & $14-17$ & $15-18$ \\
\hline 100 & $10-13$ & $17-20$ & $22-28$ & $12-15$ & $15-17$ & $21-24$ & $13-16$ & $18-19$ & $22-26$ \\
\hline Gentamycin $(10 \mu \mathrm{g} / \mathrm{ml})$ & $24-27$ & $22-26$ & $24-29$ & $23-27$ & $23-25$ & $24-28$ & $22-26$ & $25-27$ & $26-29$ \\
\hline
\end{tabular}

Flavonoids have been recognised as having a protective effect in plants against microbial invasion by plant pathogens. Flavonoids have been shown to possess important biological activities, including antifungal and antibacterial activities. This study reports that the leaves of $M$. indica contain alkaloids, anthracenosides, coumarins, flavonones, sugars, tannins, steroids and saponins. Some of these compounds have been reported to possess antimicrobial activity. Flavonoids from mango leave possess antibacterial, antifungal activities against pathogenic fungi. Since flavonoids are available at low cost and are less toxic to humans, they are highly suitable for treating such human diseases. The demonstration of activity against both Gram-negative and Gram-positive bacteria is an indication that the plant can be a source of bioactive substances that could be a broad spectrum of activity [22-29].

In conclusion, the results of the present study revealed that selected plants possess antibacterial activity. According to this study, ethanol extracts produced zone of inhibition of $6-26 \mathrm{~mm}$ against microorganisms. All the leaf extracts showed an antibacterial activity compared with the gentamycin sulphate positive control against the study organisms.

\section{CONCLUSION}

From the findings it was revealed that all the three leaves extracts of T. Grandis, M. Indica, and A. Occidantale contain bioactive compounds that are effective against the test organisms, thus the crude extracts can be used for the treatment of infections caused by the organisms. Another advantage of using these herbs as an antimicrobial agent is that there is no harmful effect on the body and there is less chance of development of resistance in bacteria against these herbs. Further studies involve the formulation of semisolid dosage forms containing individual and mixture of all the three extracts. So, herbal remedies can be recommended in various medical treatments for the cure of different disease.

\section{ACKNOWLEDGEMENT}

The authors are highly thankful to Sri CA A. Raghavendra Rao, President, Srinivas Group of Colleges, Mangalore. The authors are also thankful to Srinivas College of Pharmacy, Mangalore, India for providing necessary facilities to carry out this research work.

\section{CONFLICT OF INTERESTS}

Declared none

\section{REFERENCES}

1. Carmona F, Pereira AMS. Herbal medicines: old and new concepts, truths and misunderstandings. Braz J Pharmacognosy 2013;23:379-85.

2. Omer EU. Antibacterial and antifungal activity of ethanolic extracts from eleven spice plants. Biol Bratislava Section Cell Mol Biol 2006;61:275-8.

3. Prasannabalaji N, Muralitharan G, Sivanandan RN, Kumaran S, Pugazhvendan SR. Antibacterial activities of some Indian traditional plant extracts. Asian Pac J Trop Dis 2012;14:291-5.

4. Sharma Y, Jeyabalan G, Singh R, Semwal A. Current aspects of wound healing agents from medicinal plants: a review. J Med Plants Studies 2013;1:1-11.

5. Venkatanarayana D, Saravana KA, Lakshmi SM. Review on natural wound healing agents. Int J Phytopharm Res 2010;7:1-4.

6. Nidavani RB, Mahalakshmi AM. Teak (Tectona grandis Linn.): a renowned timber plant with potential medicinal values. Int J Pharm Sci 2014;6:48-54.

7. Abubakar EM. The antibacterial efficacy of stem bark extracts of Mangifera indica against some bacteria associated with respiratory tract infections. Sci Res Essays 2009;4:1031-7.

8. Bharti RP. Studies on antimicrobial activity and phytochemical profile of M. Indica Leaf extract. IOSR-JESTFT 2013;7:74-8. 
9. Dharamveer, Mishra B, Siddiqui HH. Pharmacognostical and phytochemical studies on Anacardium occidentale Linn. leaves. Res J Pharm Tech 2013;6:75-9.

10. Agnihotri A, Singh V. Effect of alcoholic extract of Tectona grandis Linn Heartwood against oxidative stress and diabetic and oxidative conditions. World J Pharm Pharm Sci 2013; 2:367-78.

11. Akanksha D, Vikas G, Neetesh KJ, Shailendra S, Neelam B, Dinesh KJ. Formulation and evaluation of neomycin sulphate ointment containing natural wound healing agent Curcuma longa. Int J Pharm Sci Drug Res 2009;1:116-18.

12. Amgad A, Awad EG, Joseph MRP, Ismail MM, Abdulkareem M, Hamid ME. Antimicrobial activities of seed extracts of $M$. Indica (Mangifera indica L.). Adv Microbiol 2012;2:571-6.

13. Gaikwad DD, Banerjee SK. Pharmacognostical and phytophysicochemical investigation of $M$. indica Linn. Int J Res Pharm Sci 2013:4:270-5.

14. Jaiswal Y, Naik V, Tatke P, Gabhe1, Vaidya A. Pharmacognostic and preliminary phytochemical investigations of Anacardium Occidentale (Linn.) leaves. Int J Pharm Pharm Sci 2014;4:625-31.

15. Manimegalai S, Rakkimuthu G. Phytochemical screening of stem of Couroupita guianensis. Int J Pharm Sci Res 2012;3:4434-7.

16. Preethi RM, Devanathan VV, Loganathan M. Antimicrobial and antioxidant efficacy of some medicinal plants against foodborne pathogens. Adv Biomed Res 2010;4:122-5.

17. Al-Dhabi NA, Balachandran C, Raj MK, Duraipandiyan V, Muthukumar C, Ignacimuthu S, et al. Antimicrobial, antimycobacterial and antibiofilm properties of Couroupita guianensis Aubl fruit extract. BMC Complementary Altern Med 2012;12:242-51.

18. Koleosho AT, Jose AR, Oyibo PG, Roland MA, Uloko ME. Antimicrobial activity of Sphenocentrum Jollyanum and Mangifera Indica Linn on Salmonella Typhi. J Pharm Biol Sci 2013;5:50-4.

19. Joshua M, Takudzwa M. Antibacterial properties stem bark extract of Mangifera indica on Staphylococcus aureus. Afr J Cln Exp Microbiol 2013;14:62-74.
20. Christina E, Maddox Lisa M, Laur Li Tian. Antibacterial activity of phenolic compounds against the phytopathogen Xylella fastidiosa. Curr Microbiol 2010;60:53-8.

21. Masibo $\mathrm{M}, \mathrm{He} \mathrm{Q}$. In vitro antimicrobial activity and the major polyphenol in leaf extract of M. indica L. Malaysian J Microbiol 2009;5:73-80.

22. Inamdar $\mathrm{P}$, Jelamvazir, Desai $\mathrm{S}$, Patel $\mathrm{D}$, Meshram D. Phytochemical screening and in vitro antifungal activity of Camellia sinensis. Int J Pharm Pharm Sci 2014;6:148-50.

23. Aksoy DY, Unal S. New antimicrobial agents for the treatment of Gram-positive bacterial infections. Clin Microbiol Infect 2008;14:411-20.

24. Garcia A, Rhoden SA, Bernardi WJ, Orlandelli RC, Azevedo JL, Pamphile JA. Antimicrobial activity of crude extracts of endophytic fungi isolated from medicinal plant Sapindus saponaria L. J Appl Pharm Sci 2012;2:35-40.

25. Wagnar H, Bladt S. Plant drug analysis. 2nd edition. Springer, Verlag Berlin Heidelberg; 1996. p. 359-64.

26. P Bhatt, P Negi. Antioxidant and antibacterial activities in the leaf extracts of Indian borage (Plectranthus amboinicus). Food Nutr Sci 2013;3:146-52.

27. Singh SK, Dua K, Samad A. Antimicrobial evaluation of mangiferin analogues. Indian J Pharm Sci 2009;71:328-31.

28. Negi PS. Plant extracts for the control of bacterial growth: Efficacy, stability and safety issues for food application. Int J Food Microbiol 2012;156:7-17.

29. Mohammad NS, Srinivasulu A, Chittibabu B, Rao UMV. Isolation and purification of antibacterial principle from Avicennia marina in methanol. Int J Pharm Pharm Sci 2015;7:38-41.

\section{How to cite this article}

- Krishnananda Kamath K, A Ramakrishna Shabaraya. Comparison of antibacterial activity of leaves extracts of Tectona grandis, mangifera Indica, and Anacardium Occidentale. Int J Curr Pharm Res 2017;9(1):36-39. 